found to have escaped from the centre of a large clot, conical in form, its apex pointing towards the centre of the brain; the outer layers were degenerated and buffy. The greater part of this was removed, and the cavity was thoroughly well syringed out, a large tube was inserted, the soft parts were brought together with a few sutures, and the wound was dressed antiseptically. It is worthy of note that before leaving the operation table the lest conjunctival reflex was easily obtainable. There was some recurrent hæmorrhage from the interior of the seat of the clot on the night of the operation. On the fifth and sixth days following it the patient had tbree fits very similar to chose at the commencement of his illness, but there was no further recurrence. With these exceptions his recovery was uninterrupted. The return of power in the left arm was slow, bat he eventually regained the full use of it, and when discharged he was in every respect well.

\section{ACUTE RHEUMA'TISM; HYPERPYREXIA; TREATMENT BY COLD BATH; RECOVERY.}

By NATHAN RAW, M.D., B.S., L.SAN. Sc. DURH., gaEdCAL SUPERINTENDENT AND PATHOLOGIST, DUNDEE ROYAL INFIRMARY.

HYPERPYREXIA as a complication of rheumatic fever is fortunately a very rare occurrence and unless treated promptly and vigorously is always fatal. A temperature of $207^{\circ} \mathrm{F}$. occurring rapidly and preceded or accompanied by delirium or partial unconsciousness, cessation of pain and perspiration, vomiting with cyanosis, rapid irregular pulse, and sighing respiration is generally regarded as the index of approaching death. It is now universally acknowledged that the excessively high temperature in cases of rheumatic fever, apart from the effects of micro-organisms in the blood, is the real cause of the supervention of dangerous cerebral symptoms, and therefore the attention of the physician must first of all be directed towards reducing the temperature, if possible, before the heart and the tissues generally have been too much damaged by the excessive heat. To Dr. Wilson Fox belongs the credit in this country of first employing external cold as a remedy, and the two successful cases published by him in 1870 were remarkable proofs of what could be done by prompt and vigorous treatment. Dr. Sinclair, whilst physician to the Dundee Royal Infirmary, also recorded a successful case, with a temperature of $107 \cdot 4^{\circ}$, in 1882 . The following is a short history of the case under notice.

A woman forty-eight years of age was admitted into Ward 9 of the Dundee Royal Infirmary, under the care of Dr. Stalker, on April 15th, 1894, suffering from acute rheumatism. The patient was in this infirmary seven years previonsly suffering from an attack of the same malady, which ran an ordinary course. The present illness commenced a week before her admission with what appears to have been acute tonsillitis; she had been living by herself and been neglected in consequence. When admitted at 1 P.M. she complained of severe pain in both shoulders, elbows, and wrists, and was unable to move her arms without suffering great pain. Her temperature was $104 \cdot 2^{\circ} \mathrm{F}$, and there was no swelling or redness of the joints. She had an anxious and flushed appearance; the skin was hot and dry, the breath offensive; the respiration was 36 , and the pulse 120, soft, and regular. She had a soft, blowing, systolic murmur, heard only in the mitral area, and accentuation of the aortic second sound. There were sudamina over the abdomen and chest. Mentally she was quite clear and cheerful. She was at once ordered the following mixture: Gifteen grains of salicylate of soda, ten grains of bicarbonate of notassium, and fifteen minims of spirit of aromatic ammonia, to half an onnce of water, to be taken every four hours, and the painful joints to be wrapped in wool. At 4 P.M. (three bours after admission) the sister reported her temperature to be $108^{\circ}$. I at once went to the patient and found a remarkable change in her condition. She was quite unconscious, langhing and shouting incoherently ; face cyanosed; pupils contracted; skin hot and dry; the joints were moved without causing pain; pulse 152 and very small. She was aridently dying, so it was decided to act at once. A bath was prepared at a temperature of $100^{\circ}$; the patient was given one ounce of brandy and at once placed in the bath, which was cooled down to $66^{\circ}$ by the addition of cold water and ice.
The following tabular statement is an accurate record of the observations taken at the time :-

\begin{tabular}{|c|c|c|c|}
\hline Time. & $\begin{array}{c}\text { Temp. of } \\
\text { bath. }\end{array}$ & $\begin{array}{l}\text { Temp. of } \\
\text { patient. }\end{array}$ & Remarks. \\
\hline 4.15 P.M. & $100^{\circ} \mathrm{F}$. & $108^{\circ} \mathrm{F}$. & $\begin{array}{l}\text { Patient placed in bath; quite } \\
\text { unconscious and wildy de- } \\
\text { lirious ; constant vomiting } \\
\text { pulse } 154 \text {. }\end{array}$ \\
\hline 4.20 Р.м. & $96^{\circ}$ & $108^{\circ}$ & $\begin{array}{l}\text { Quieter; more brandy poured } \\
\text { into mouth ; gasping respira. } \\
\text { tion; pulse 150. }\end{array}$ \\
\hline 4.25 P.M. & $90^{\circ}$ & $106^{\circ}$ & $\begin{array}{l}\text { Vomiting continued ; respiration } \\
\text { improved ; pulse almost im. } \\
\text { perceptible; struggling. }\end{array}$ \\
\hline 4.30 P.M. & $66^{\circ}$ & $102^{\circ}$ & $\begin{array}{l}\text { Struggling violently and scream. } \\
\text { ing; taken out of bath and } \\
\text { removed to bed. }\end{array}$ \\
\hline 4.35 P.M. & - & $97^{\circ}$ & $\begin{array}{l}\text { A remarkable change, patient } \\
\text { shivering and quite sensible; } \\
\text { skin cool and showing cutis } \\
\text { anserina ; only one sound of } \\
\text { heart heard; pulse } 120 \text {, very } \\
\text { small ; pupils more dilated; } \\
\text { not so cyanosed ; given more } \\
\text { brandy) }\end{array}$ \\
\hline
\end{tabular}

The temperature, it will be seen, had dropped $11^{\circ}$ in twenty minutes. The delirinm entirely passed off, and she felt comfortable. I watched carefully for the return of the temperature, keeping a thermometer in each axilla. In fifteen minutes it began to rise rapidly, until it reached $102^{\circ}$. She was kept constantly sponged with iced water over the chest and abdomen, and ice was applied to the head and base of neck ; this had the effect of keeping down the temperature. In a few minutes, however, she developed a maniacal attack, shouting, screaming, and struggling, with marked delusions of fear. This lasted twenty minutes, when she suddenly became quiet and quite sensible. She was given salicylate every two hours. From this time the temperature has remained practically normal ; the pain has entirely disappeared, and she expresses herself as feeling quite well.

This case is highly instructive from the fact that not only was the temperature suddenly reduced, and, in consequence, her life saved, but the attack of rheumatic fever was cut short or aborted, and, as will be seen from the chart, since the day of admission her temperature never exceeded $100^{\circ}$, with total disappearance of joint pain and all other rheumatic

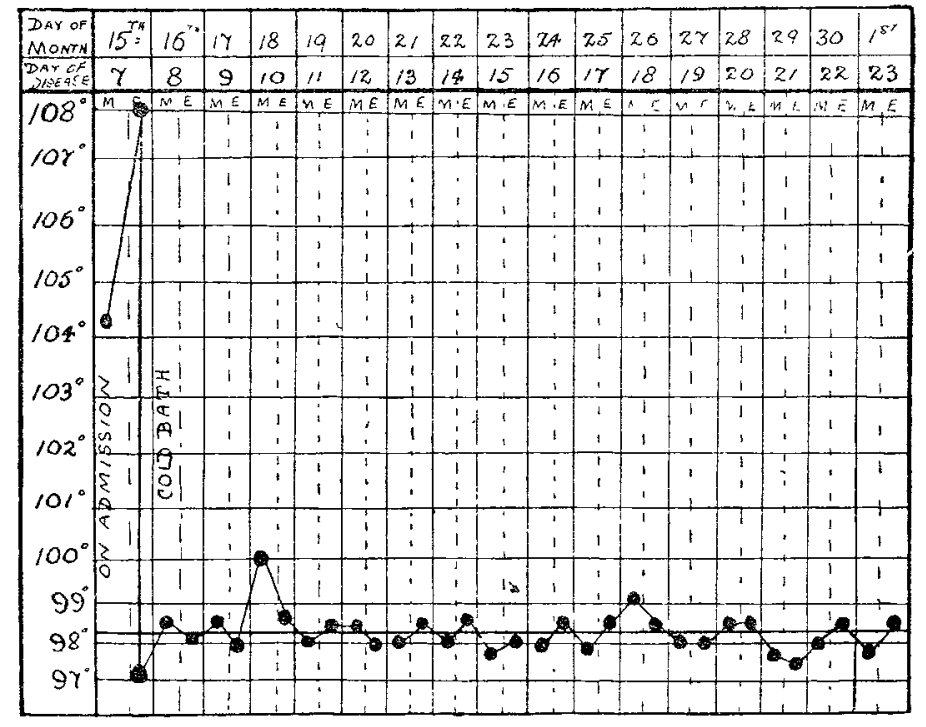

symptoms. Of course a good deal of this good result was no doubt due to the salicylate and alkaline treatment, being combined with the local treatment; but the question is, Should attacks of rheumatic fever with a high temperature of $103^{\circ}$ or $104^{\circ}$ not be treated on the same principle, and an endeavour be made to at once reduce the temperature and cut short the attack? Many cases of acute rheumatism continue this high temperature, ranging from $102^{\circ}$ to $104^{\circ}$ for weeks, slowly destroying the patient's vitality, and leaving permanent legacies, such as endocarditis, chorea, \&c. The cold bath would, of course, only be used in extreme cases. Whatever be the exact cause of the disease, whether excess of uric acid, lactic acid, a bacillus, or an organic poison in the 
blood, it is evident that it flourishes with the blood at a high temperature and is not so active in a temperature below $100^{\circ}$; it is also evident that the hyperpyrexia was the cause of the delirium, unconsciousness, and maniacal outburst, from the fact that these symptoms immediately subsided with the reduction of the temperature.

\section{THROMBOSIS AFTER INFLUENZA.}

BY JULIUS ALTHAUS, M.D., M.R.C.P. LoND., CONSULTING PHYSICIAN TO THE HOSPITAL FOR EPILEPSY AND PARALYSIS, REGENT S PARK.

IN a former number of THE LANCET ${ }^{2}$ Dr. Stevenson has described an interesting case of gangrene of the bowel subsequent to influenza and owing to thrombosis, which was favoured by previously existing arterial disease. He adds : "Thrombosis is, I believe, a fairly frequent sequel of influenza." Such is, indeed, the case. In my book on Influenza I have referred to instances of thrombosis of arteries after that disease, some of them followed by gangrene, described by Leichtenstern, Duchesneau, Highet, Eichhorst, Sydenham, Senator, Gerhardt, Cammerer, and Cross. Since then other cases have been recorded in the German Collective Investigation Report ${ }^{2}$ by Professor Litten, who has collected twenty-five cases of venous thrombosis, affecting chiefly the femoral vein, and eight cases of arterial thrombosis, in five of which one or both popliteal arteries were affected, while the femoral, brachial, and cerebral arteries suffered in one case each. Subsequently Leyden ${ }^{3}$ has described a highly interesting case of spontaneous thrombosis of the left brachial artery after influenza. The patient was a young woman aged twenty, who was laid up with a feverish attack in January, 1892. After being in bed for a week she recovered and had three weeks subsequently-a sequence by no means uncommon-tonsillitis resulting in an abscess, which healed in a week. Shortly afterwards a pricking pain came on in the left hand, which latter appeared at first pale, but presently became livid, cold, and powerless. The temperature of the affected hand was more than $6^{\circ} \mathrm{C}$. lower than that of the sound one; there was slight anæsthesia in parts, and wasting in the muscles of the forearm and hand, with the electric signs of slight "reaction of degeneration." The left radial pulse was absent, and a thrombus about an inch and a half long could be felt in the left brachial artery just above the elbow. Above this thrombus the artery pulsated powerfully, while below it no pulsation was perceptible. The patient had no cardiac or arterial disease, and the affection could therefore only be attributed to the preceding attack of influenza. She gradually regained the use of the hand, which also recovered its normal appearance and temperature, although the left radial artery remained blocked. Litten is inclined to consider spontaneous arterial thrombosis after influenza to be identical with Virchow's "marantic thrombosis," which is seen after typhoid fever and other exhausting diseases; but Leyden has given a more satisfactory explanation of the occurrence. He does not believe that a short attack of influenza leads to actual marasmus, and in the majority of cases of arterial thrombosis which have been described there has been no previous disease of either the heart or the arteries. It therefore appears more probable that the coagulation of blood in the living artery is rather owing to the breaking-up of the white blood-cells, which become superabundantly developed in the blood from the very beginning of the feverish attack and even after the crisis. After a time these cells break up into fragments, forming the so-called "blood plates." Such blood plates may, by adhering in masses to certain points of the arterial wall, cause coagulation in such a spot and thus lead to the formation of a thrombus in the vessel. This view of the matter seems to be confirmed by Heintz's ${ }^{4}$ observations on thrombosis after arsenical poisoning. He has shown that in such cases arterial as well as venous thrombosis originates from the breaking-up of the white blood cells and

\section{THE Lancet, Jan. 21st, 1893.}

2 Die Influenza-Epidemie, 1889-90, \&c. Herausgegeben von Dr. E. Leyden und Dr. S. Guttmann. P. 85 . Wiesbaden, 1892 3 Deutsche Medicin. Wochenschrift, Nov. 10th, 1892 4 Virchow's Archiv, vol, exxvi, p. 495. their transformation into "blood plates." Similar occurrences, moreover, have been noticed after poisoning with phosphorus and chlorate of potash, so that mineral poisons as well as toxines appear to be able to give rise to spontaneous arterial thrombosis in the way just described and without the intervention of marasmus.

Harley-street, W.

\section{THE NOTES OF A CASE OF MALIGNANT} STRICTURE OF THE CESOPHAGUS

$$
\text { TREATED BY INTUBATION. }
$$

\section{BY ALFRED BERRILL, M.R.C.S. ENG., L.R.C.P. LOND.}

IN the early part of November, 1892, I saw a man who complained of hoarseness lasting since September of the same year. During the whole of 1891 and the early part of 1892 he had been laid up with subacute rheumatism and pneumonia. He had a very old history of syphilis. In August, 1892, he experienced a little difficulty in swallowing for the first time. In September he became hoarse. But he had gained in weight since his long illness, and looked hearty and well. On Nov. 4th I saw him in consultation with Mr. Hovell ; it was then found that his right vocal cord was motionless, that a good-sized cesophageal bongie could not be passed beyond a point eight inches from the teeth, and that his right supra-clavicular glands were enlarged. Ultimately a $N 0.6$ Mackenzie's bougie was passed through the stricture. It was conciuded that he had malignant stricture of the œsophagus. On Dec. 2nd he had lost $6 \mathrm{lb}$. in weight in three weeks; the swallowing was no worse, but the glandular swelling was larger. Early in January, 1893, the swallowing was much worse and the patient weaker; one of Mr. Symonds' short tubes (No. 10) was passed and left in the cesophagus, and the patient was at once able to drink some milk. The tube was changed for a new one every ten to fourteen days; the size that answered best was a No. 12 six-inch tube with double silk each side. The silk from each side of the tube was tied together just outside the mouth, as the stricture was so high up and the patient found he could not tolerate any knots in the pharynx or touching the back part of the tongue. A No. 15 short tube was tried, but this did not answer owing to pressure on the cricoid cartilage. His diet consisted of warm beef-tea, somp, and milk, with the yolk of two or three eggs a day; all the food was carefully strained through muslin. On April 10th Mr. Symonds kindly saw him with me, and adrised that the tube should be left out, but that a No. 12 (urethral) bougie should be passed each day for two or three days and then on alternate days, or at longer periods if possible, so long as the swallowing remained good, or provided the bougie could be passed easily. The patient found be could swallow a teacupful of pounded meat in gravy if he carefully "washed each mouthful down" with water. The plan of leaving the tabe out answered well for twelve days, but at the end of that time it was found impossible to introduce the tube in the ordinary way with the whalebone and gum elastic introducer. The following plan was then tried with success : a No. $6 \mathrm{gum}$ elastic catheter (no small bougie was at hand) was passea just through the stricture, and an open-ended No. 12 short tube was passed over the catheter, using that as a guide. The tabe was then laft in for three days only, whereupon the patient was able to swallow without the tube with comfort for another twelve days. when the tube was reintroduced for three more days. This treatment was continued for seven months, until the patient's death. In July it was found that his liver was enlarging rapidly, and this was accompanied with troublesome diarrhea: there were no pulmonary symptoms, and the cord remained paralysed. He died in August, 1893, twelve months after the first symptoms, from exhaustion. No post-mortem examination was allowed.

It was a great relief to the patient and those around him to be able to adopt some measure that enabled him to swallow with comparative comfort. A few days before the first tube was introduced in January be had the greatest diffeculty in swallowing anything, and, in fact, for one day he was quite unable to swallow at all. These cases are always most trying, especially in general practice, and having lately had a case of this terrible disease where Mr. Symonds" tube was not used, I can quite appreciate how 